\title{
PENERAPAN PEMBELAJARAN KOOPERATIF MODEL EXAMPLES NON EXAMPLES DAN STAD PADA MATA KULIAH STRUKTUR HEWAN PROGRAM STUDI PENDIDIKAN BIOLOGI
}

\author{
Hening Widowati \\ Pendidikan Biologi FKIP Universitas Muhammadiyah Metro
}

\begin{abstract}
The research aims to overcome learning difficulties by implementing cooperative learning model "Examples and Non Examples STAD" through activity Lesson Study in Animal Structure college activities. Preliminary research by studying the documentation, observation, and limited interviews to faculty and students about the usual lectures in Biology Education courses. Retrieval of data using the method of documentation, observation, tests, and interviews. Data were analyzed descriptive qualitatively. Preliminary research findings indicate that the material is abstract and the Basic Tissues are not related to daily life so it needs to concretisation process ; classes force lecturers held a Biology major classical learning, making it more difficult for understanding because students tend to be a listener only and not make the learning process. To overcome the disadvantages of learning in the college made the development of media in the form of a slides lecture that was presented on the LCD, especially for concreting material, students completed worksheets to conduct discussions and small group work activities, sheet test to determine student understanding, and cooperative learning model performed Examples of Non Examples and STAD through Lesson Study activities at the college activities by empowering collaborative work in small groups. Use of the method in this lecture can improve learning activities that were previously only $38.916 \%$ to about 73.930 to $77.833 \%$, and all indicators of learning activities can be achieved. The results of the previous lecture that the average score of only 57.759 to 77.155 on Lesson Study2, so the increased is $33.581 \%$. Based on the data obtained can be concluded implementation of cooperative learning model Examples and Non Examples STAD through Lesson Study in Animal Structure college activities can be a solution to overcome the difficulties learning materials Basic Tissues, which demonstrated the increased activity and student learning outcomes.
\end{abstract}

Kata kunci: examples non examples, STAD, struktur hewan, lesson study

Pendidikan dibangun atas empat pilar terdiri dari belajar untuk mengetahui (learning to know), belajar untuk melakukan (learning to do), belajar untuk menjadi diri sendiri (learning to be), dan belajar untuk kebersamaan (learning to live together). Keempat pilar tersebut menurut UNESCO (Anonim, 2006) merupakan pedoman yang penting digunakan dalam pembelajaran Sains di kelas.

Pembelajaran Sains, termasuk Biologi, tidak seharusnya hanya mendudukkan pebelajar sebagai pendengar ceramah dan dosen memerankan diri sebagai pengisi otak pebelajar yang mengikuti kuliah yang dianggap tidak mengerti apa-apa yang perlu diisi ilmu pengetahuan, sebagaimana biasa dilakukan dalam proses/kegiatan kuliah. Mahasiswa harus diberdayakan agar mau dan mampu berbuat untuk memperkaya pengalaman belajarnya (learning to do).
Dengan meningkatkan interaksi dengan lingkungan fisik dan sosialnya, diharapkan mahasiswa mampu memahami pengetahuannya berkaitan dengan dunia sekitarnya (learning to know). Dari hasil interaksi dengan lingkungannya diharapkan mahasiswa dapat membangun pengetahuan dan kepercayaan diri sekaligus membangun jati diri (learning to be). Kesempatan berinteraksi dengan individu dalam kelompok yang bervariasi akan membentuk kepribadiannya untuk memahami kemajemukan dan melahirkan sikap-sikap positif dan toleran terhadap keanekaragaman dan perbedaan masing-masing individu (learning to live together). Dalam konteks ini, mahasiswa perlu dilatih bekerjasama, dan menemukan pendapat berbeda namun mahasiswa diharapkan masih tetap bersikap kritis. 
Biologi sebagai ilmu, salah satu cabang Sains, dapat dipelajari dengan baik dan tujuan pembelajaran dapat dicapai, apabila dalam pembelajarannya terjadi interaksi yang baik dan efektif antara dosen, mahasiswa, dengan medium bahan pembelajaran materi Biologi.

Sebagaimana diketahui, materi-materi Biologi beragam, ada yang konkrit, tetapi banyak juga yang abstrak, sehingga relatif lebih sulit dipahami mahasiswa, di antaranya tentang Struktur Hewan khususnya pembahasan tentang Jaringan Dasar. Materi Jaringan Dasar kurang diminati pebelajar, selain menjenuhkan karena bersifat mikroskopik sehingga cukup sulit untuk memahaminya, juga kurang berhubungan dengan dunia nyata dan kehidupan seharihari. Oleh karena itu, untuk dapat menguasai Biologi pada materi yang abstraks dengan baik perlu didukung metode yang sesuai dengan kondisi mahasiswa dan lingkungan belajar yang tepat. Faktor yang mempengaruhi proses dan hasil belajar Biologi di antaranya dosen, mahasiswa, dan metode yang digunakan. Hubungan yang sinergis antara ketiga komponen tersebut diharapkan mengarah pada cara belajar aktif, karena selama ini kegiatan kuliah Biologi dilaksanakan secara klasikal dengan metode ceramah serta menghafal tanpa memahami makna materi kuliahnya. Proses perkuliahan menjadi kurang efektif sehingga mahasiswa banyak yang kurang aktif dalam belajar, dan menyebabkan aktivitas belajar yang diperoleh rendah. Dosen berperan dalam upaya meningkatkan aktivitas dan hasil kuliah dengan cara memberikan kesempatan kepada mahasiswa untuk belajar dengan teman sebayanya dan mahasiswa dapat saling bertukar informasi materi pada saat perkuliahan berlangsung melalui pembelajaran kooperatif.

Pembelajaran kooperatif merupakan metode pembelajaran dengan mengedepankan pemanfaatan kelompok kecil dengan struktur bersifat heterogen, mahasiswa belajar dan melakukan kegiatan dalam kelompok-kelompok kecil secara kolaboratif. Ciri pembelajaran kooperatif menurut Carin (1993) adalah 1) Setiap anggota memiliki peran; 2) Terjadi interaksi langsung di antara anggota kelompok; 3) Setiap anggota kelompok bertanggungjawab atas belajarnya dan juga teman-teman sekelompoknya; 4) Dosen berinteraksi dengan kelompok saat diperlukan. Selanjutnya dikemukakan oleh Slavin (1995), bahwa ada tiga konsep sentral yang menjadi karakteristik pembelajaran kooperatif, yaitu penghargaan kelompok, pertanggungjawaban individu; dan kesempatan yang sama untuk berhasil; dengan tujuan menciptakan situasi, bahwa keberhasilan individu ditentukan atau dipengaruhi oleh keberhasilan kelompok (Slavin, 1994).

Pada pembelajaran kooperatif dapat digunakan metode-metode efektif interaktif di antaranya Example Non Example dan STAD (Student Team Achievement Division)/Tim Pebelajar Kelompok Prestasi. Examples Non Examples adalah metode pembelajaran menggunakan contoh-contoh dari gambar yang relevan dengan kompetensi dasar. Kompetensi dasarnya adalah pemahaman struktur jaringan epithelium, karena itu ditunjukkan berbagai contoh dan ilustrasi struktur jaringan epithelium. Dosen menyiapkan gambar-gambar sesuai dengan tujuan perkuliahan; menayangkan gambargambar melalui LCD; memberi petunjuk dan kesempatan pada mahasiswa memperhatikan dan menganalisa gambar; melalui diskusi kelompok 3-5 mahasiswa, hasil analisa gambar dicatat, selanjutnya diminta untuk membacakan hasil diskusinya; selanjutnya dosen menjelaskan materi sesuai tujuan yang ingin dicapai; dan merumuskan kesimpulan.

Model pembelajaran kooperatif tipe STAD dikembangkan oleh Robert E. Slavin (dalam Nurmuhammad, 2000) dan temantemannya di Universitas Jhon Hopkin, dan merupakan tipe pembelajaran kooperatif yang paling sederhana. Dosen yang mengunakan STAD mengacu kepada belajar kelompok mahasiswa yang menyajikan informasi akademik kepada mahasiswa menggunakan persentasi verbal atau teks. Pembelajaran kooperatif tipe STAD membagi mahasiswa dalam kelompok-kelompok kecil 
yang terdiri dari 4 sampai 5 orang yang bersifat heterogen. Komponen utama tipe $S T A D$ adalah presentasi kelas, kegiatan kelompok, kuis/test, pemberian skor individu dan penghargaan kelompok.

Tabel 1. Rata-rata Postes Mata Kuliah Struktur Hewan Kelas B Program Studi Pendidikan Biologi FKIP Universitas Muhammadiyah Metro

\begin{tabular}{|c|c|c|c|c|}
\hline No. & Nilai & Jumlah Mahasiswa & $\mathbf{\%}$ & Kriteria \\
\hline 1. & $\geq 70$ & 13 & 22,414 & Tuntas \\
\hline 2. & $<70$ & 45 & 77,586 & Tidak tuntas \\
\hline \multicolumn{2}{|r|}{ Jumlah total mahasiswa } & 58 & $100 \%$ & \\
\hline
\end{tabular}

Sumber: Daftar Nilai Kegiatan Perkuliahan Struktur Hewan Kelas B Program Studi Pendidikan Biologi FKIP Universitas Muhammadiyah Metro

Model pembelajaran kooperatif tipe STAD ini tepat untuk diterapkan bagi kelaskelas yang masih menggunakan model pembelajaran secara langsung karena sangat mudah diterapkan dan paling sederhana dalam penerapannya. Mahasiswa akan lebih mudah dalam menemukan dan menangani konsep-konsep yang sulit jika mereka saling mendiskusikan masalah tersebut dengan temannya. Mahasiswa yang berkemampuan rendah mendapat kesempatan untuk dibimbing oleh temannya yang memiliki wawasan yang lebih tinggi, sedangkan mahasiswa yang lebih tinggi kemampuannya mempunyai kesempatan untuk menjadi tutor sehingga pemahamannya menjadi lebih baik lagi. Kerja kelompok diharapkan dapat membuat mahasiswa lebih mendiskusikan konsep dan prinsip tentang pelajaran mereka. Kegiatan saling membantu yang menguntungkan semua pihak tentu akan meningkatkan hasil belajar mahasiswa sehingga aktivitasnyapun akan meningkat. Pemilihan kedua metode didasarkan pada hasil prasurvei dan observasi diperoleh data hasil postes dua kali pertemuan kuliah dengan rata-rata skor 57,759 , dengan rincian nilai tertera pada Tabel 1 .

Hasil observasi menunjukkan bahwa hasil kuliah Struktur Hewan mahasiswa kelas B program studi Pendidikan Biologi masih banyak yang belum tuntas, karena kebanyakan masih di bawah standar ketuntasan belajar, yaitu nilai kurang dari Kriteria Ketuntasan Minimal (KKM) 70, sejumlah 77,586\%. Rendahnya hasil kuliah
Struktur Hewan diduga merupakan dampak berbagai masalah yang muncul dalam kegiatan perkuliahan. Berdasarkan hasil wawancara dengan sejumlah mahasiswa, peneliti dapat mengidentifikasi bahwa belum tuntasnya kuliah, karena aktivitas belajar ketika kuliah masih kurang. Beberapa petunjuk kurangnya hasil belajar mahasiswa Pendidikan Biologi semester 5 kelas B, dapat dilihat dari: 1) Kebanyakan mahasiswa tidak bisa menjawab ketika diberi pertanyaan, baik lesan maupun tertulis; 2) Minimnya mahasiswa yang bertanya saat perkuliahan berlangsung; 3) Saat mengerjakan soal, tidak percaya diri, berusaha menyontek catatan atau hasil pekerjaan temannya; 4) Kurang motivasi dan minat mahasiswa dalam kegiatan perkuliahan, yang ditunjukkan dengan kurang memperhatikan dan tidak mendengarkan saat dosen menyampaikan materi kuliah; 5) Sebagian besar mahasiswa cenderung pasif, hanya bertindak sebagai pendengar; 6) Mahasiswa yang kemampuan tinggi cenderung egois dan individualistik, tidak mau berbagi pengetahuan dengan sesama teman yang kemampuannya rendah.

Permasalahan-permasalahan yang menunjukkan kurang berhasilnya proses belajar dalam kuliah disebabkan oleh perkuliahan yang pembelajarannya masih bersifat klasikal dan berorientasi pada dosen, serta mendudukkan mahasiswa sebagai pendengar ceramah dengan dosen memerankan diri sebagai pengisi informasi materi kuliah. 
Fakta yang diperoleh dari observasi, memberi dasar peneliti untuk melakukan perbaikan proses perkuliahan dengan melibatkan masukan teman sejawat dalam program studi Pendidikan Biologi dalam merencanakan, melaksanakan, dan melakukan refleksi, sebagai solusi untuk meningkatkan proses dan hasil belajar mahasiswa, yaitu mengubah pembelajaran klasikal dengan mengganti pembelajaran inovatif, kreatif, dan menyenangkan, yaitu dengan menerapkan metode pembelajaran kooperatif Examples Non Examples serta Student Teams Achivement Division (STAD). Metode pembelajaran ini dipilih didasarkan adanya kecenderungan mahasiswa prinsipnya menyukai kerjasama, dan sebagai upaya dosen untuk memberdayakan mahasiswa yang memiliki kemampuan akademik tinggi untuk membantu mahasiswa yang kemampuannya rendah. Sehingga penggunaan metode ini dalam perkuliahan diharapkan mahasiswa akan lebih aktif dalam perkuliahan yang selanjutnya dapat meningkatkan proses/aktivitas dan hasil belajarnya.

Berdasarkan uraian pada pendahuluan dapat dikemukakan bahwa pembelajaran kooperatif dengan menggunakan metodemetode pembelajaran efektif di antaranya dalam perkuliahan Struktur Hewan penting dilakukan. Oleh karena itu perlu dilakukan Lesson Study secara terprogram dengan menerapkan penggunakan metode Example Non Example dan STAD (Student Team Achievement Division)/Tim Pebelajar Kelompok Prestasi dalam perkuliahan Struktur Hewan di program studi Pendidikan.

\section{METODE}

Penelitian dilakukan dengan diawali kegiatan survei dan observasi pada pelaksanaan perkuliahan di program studi Pendidikan Biologi, yang difokuskan pada perolehan pengalaman dan pendapat mahasiswa tentang aktivitas proses kuliah dan informasi perolehan hasilnya dari dosen. Berdasarkan data awal tersebut, dilakukan perencanaan (plan) bersama teman dosen sejawat dengan fokus pembelajaran kooperatif pada materi Jaringan Dasar. Selanjutnya dilakukan tindakan dan observasi (do) pada pelaksanaan kuliah, dan terakhir dilakukan refleksi (see) untuk melihat kelemahan dan sekaligus melakukan perbaikan pada perencanaan perkuliahan berikutnya. Rancangan penelitian tersebut dapat digambarkan sebagaimana gambar 1 .

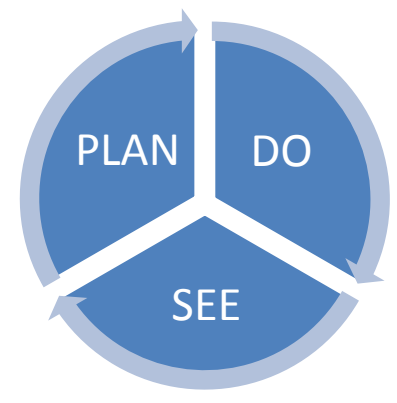

\section{Gambar 1. Rancangan Penelitian}

Pengambilan data dilakukan melalui dokumentasi, observasi, dan tes hasil perkuliahan. Dokumentasi yang digunakan dalam penelitian ini adalah perangkat pembelajaran meliputi Analisis Instruksional, Satuan Acara Perkuliahan (SAP), Rencana Pelaksanaan Perkuliahan (RPP), Jadwal Kuliah, Lembar Kerja Mahasiswa, Lembar Tes/Evaluasi, serta rekaman video. Observasi dilakukan terhadap aktivitas dosen dan mahasiswa dalam perkuliahan Struktur Hewan kelas B program studi Pendidikan Biologi, khususnya dalam penerapan pembelajaran kooperatif dengan menggunakan metode Example Non Example dan STAD (Student Team Achievement Division)/Tim Pebelajar Kelompok Prestasi. Tes digunakan untuk memperoleh informasi hasil perkuliahan baik melalui kegiatan kelompok maupun evaluasi individual, dengan harapan memperoleh informasi komprehensif mengenai adanya perubahan/peningkatan pada proses/aktivitas belajar serta hasilnya baik pebelajar sebagai individu maupun kemampuannya dalam kelompok belajar yang tidak hanya mengembangkan pemahaman materi, tetapi juga personal dan interpersonal mahasiswa.

Pengolahan data dilakukan secara deskriptif kualitatif untuk memperoleh 
gambaran tentang penerapan pembelajaran kooperatif dengan menggunakan metodemetode pembelajaran efektif dalam perkuliahan Struktur Hewan. Lesson Study dilakukan secara terprogram dengan menerapkan penggunaan metode Example Non Example dan STAD (Student Team Achievement Division)/Tim Pebelajar Kelompok Prestasi dalam perkuliahan Struktur Hewan di program studi Pendidikan. Prosedur analisis data diawali dengan data tentang aktivitas belajar dalam perkuliahan, yang diperoleh dari lembar observasi , dengan menghitung rata-rata dari masingmasing indikator, yaitu memperhatikan dosen ketika menjelaskan, menjawab pertanyaan, mengemukakan pendapat, mengajukan pertanyaan, mengerjakan latihan pada lembar kerja mahasiswa, aktif berdiskusi dengan teman, dan membuat catatan/merangkum. Data tentang hasil belajar perkuliahan Jaringan Dasar berupa skor hasil tes dilakukan dengan membandingkan skor nilai tes pada Lesson Study 1 dan 2, baik skor nilai individual maupun kelompok. Data dianalisis untuk melihat peningkatannya antara sebelum dilakukan Lesson Study, maupun setelah dilakukan Lesson Study 1 dan 2.

Aktivitas pembelajaran yang baik, peneliti mengacu pada pendapat Nurkancana (2005), bahwa proses pembelajaran dikatakan baik, bila ditunjukkan aktivitas belajar di kelas memenuhi kriteria sebagai berikut: 1) Memperhatikan guru menerangkan $\geq 95 \%$; 2) Menjawab pertanyaan guru $\geq 80 \%$; 3) Mengeluarkan pendapat $\geq 10 \%$; 4) Bertanya $\geq 10 \%$; 5)Mengerjakan latihan $\geq 55 \%$; 6) Aktif berdiskusi dengan teman $\geq 30 \%$; 7) Mencatat/merangkum $\geq 95 \%$.

\section{Hasil dan Pembahasan}

Data dokumentasi pada penelitian pendahuluan, meliputi perangkat pembelajaran jadwal kuliah, jadwal praktikum, petunjuk praktikum; menunjukkan bahwa perkuliahan Struktur Hewan umumnya menggunakan metode ekpositori klasikal, yang dikombinasi dengan penggunaan media-media charta, serta kegiatan praktikum terpisah dengan perkuliahan. Penggunaan metode lain pada kegiatan klasikal terbatas digunakan dengan alasan kelas Biologi yang besar, dengan jumlah mahasiswa setiap tatap muka melebihi 55 mahasiswa.

Hasil diskusi dengan dosen sejawat, menunjukkan adanya kendala menerapkan metode-metode pembelajaran efektif karena jumlah mahasiswa dalam kelas yang besar. Untuk materi tertentu khususnya yang abstrak perlu dicari solusi, dengan harapan memudahkan mahasiswa belajar dan meningkatkan pemahamannya, apalagi waktu untuk melakukan kegiatan praktikum yang terbatas sehingga pemahamannya menjadi rendah.

Hasil wawancara dengan mahasiswa, ditemukan semua mahasiswa mengalami kesulitan dalam memahami materi Jaringan Dasar Hewan karena konsep-konsepnya terlalu abstrak, mikroskopik, dan tidak berhubungan dengan kehidupan sehari-hari. Berdasarkan hasil wawancara dengan mahasiswa juga diperoleh masukan perlunya visualisasi dari kajian materi Jaringan Dasar, perlunya pendekatan kontekstual, serta adanya kegiatan lain dalam kuliah selain mendengarkan penjelasan dosen sehingga diupayakan adanya kegiatan lain dapat lebih memahamkan mahasiswa dan dapat mengembangkan potensi-potensi lain dalam diri mahasiswa.

Berdasarkan hasil penelitian pendahuluan, dilakukan analisis mendalam untuk menentukan masalah yang sebenarnya dalam perkuliahan Struktur Hewan khususnya materi Jaringan Dasar. Hasil analisis menemukan bahwa masalah dalam perkuliahan Struktur Hewan adalah karena konsep materinya yang abstrak, sehingga dalam perencanaan perkuliahan perlu dipilih metode untuk memvisualisasi materi serta diberikan kegiatan lain yang memungkinkan mahasiswa terlibat langsung dalam pembelajaran serta keterlibatan teman sejawat untuk saling membantu memahamkan konsep materi, di samping juga memberi peluang berkembangnya hubungan interpersonal dalam kelompok 
kecil sehingga potensi-potensi lain dapat dikembangkan, misalnya kerjasama, tanggungjawab, saling percaya, menghargai pendapat teman, saling membantu, menghilangkan sikap egois, serta meningkatkan motivasi intrinsik. Metode yang digunakan adalah Example Non Example dan STAD (Student Team Achievement Division)/Tim Pebelajar Kelompok Prestasi dengan pendekatan pembelajaran kooperatif dalam kegiatan klasikal dan kelompok kecil. Media slide dalam $L C D$ digunakan agar memungkinkan keterlibatan aktif mahasiswa dalam pembelajaran.

Berdasarkan data penelitian pendahuluan dirancang perkuliahan Lesson Study 1, yaitu menggunakan model pembelajaran Examples Non Examples (menggunakan contoh-contoh dari gambar yang relevan dengan kompetensi dasar). Kompetensi dasarnya adalah pemahaman struktur jaringan epithelium, karena itu ditunjukkan berbagai contoh dan ilustrasi struktur jaringan epithelium. Dosen menyiapkan gambar-gambar sesuai dengan tujuan perkuliahan; menayangkan gambargambar melalui $L C D$; memberi petunjuk dan kesempatan pada mahasiswa memperhatikan dan menganalisa gambar; melalui diskusi kelompok 3-5 mahasiswa, hasil analisa gambar dicatat, selanjutnya diminta untuk membacakan hasil diskusinya; selanjutnya dosen menjelaskan materi sesuai tujuan yang ingin dicapai; dan merumuskan kesimpulan. Perkuliahan pada Lesson Study 2 menggunakan model pembelajaran Student Team-Achievement Division (STAD)/Tim Siswa Kelompok Prestasi. Mahasiswa dibagi dalam kelompok heterogen. Dosen menyajikan materi kuliah secara umum. Selanjutnya dosen memberikan tugas kelompok untuk dikerjakan seluruh anggota kelompok. Anggota yang sudah mengerti menjelaskan kepada anggota lainnya, sampai seluruh anggota dalam kelompok memahami materi itu. Dosen memberi kuis/pertanyaan kepada seluruh mahasiswa, dengan tanpa dibantu lainnya, selanjutnya diadakan evaluasi, dan diakhiri dengan perumusan kesimpulan.

Hasil observasi terhadap pelaksanaan perkuliahan Struktur Hewan khususnya materi Jaringan Dasar diperoleh hasil yang disajikan pada Tabel 2.

Tabel 2. Data Hasil Observasi Pelaksanaan Perkuliahan Struktur Hewan Materi Jaringan Dasar

\begin{tabular}{|c|c|c|c|c|c|c|c|c|}
\hline \multirow[t]{2}{*}{ No. } & \multirow[t]{2}{*}{ Indikator } & \multirow[t]{2}{*}{$\begin{array}{c}\text { Target } \\
\%\end{array}$} & \multicolumn{6}{|c|}{$\begin{array}{l}\text { Target Aktivitas Perkuliahan } \\
\text { (frekuensi/\%) }\end{array}$} \\
\hline & & & $\begin{array}{l}\text { Sebelum } \\
\text { L.S }\end{array}$ & Target & L.S1 & Target & L.S2 & Target \\
\hline 1. & $\begin{array}{l}\text { Memperhatikan } \\
\text { penjelasan } \\
\text { dosen }\end{array}$ & $\geq 95$ & $50 / 86,207$ & $\begin{array}{c}\text { Belum } \\
\text { tercapai }\end{array}$ & $55 / 94,827$ & $\begin{array}{c}\text { Belum } \\
\text { tercapai }\end{array}$ & $58 / 100$ & Tercapai \\
\hline 2. & $\begin{array}{l}\text { Mencatat dan } \\
\text { merangkum }\end{array}$ & $\geq 95$ & $57 / 98,276$ & Tercapai & $58 / 100$ & Tercapai & $58 / 100$ & Tercapai \\
\hline 3. & Bertanya & $\geq 10$ & $4 / 6,897$ & $\begin{array}{c}\text { Belum } \\
\text { tercapai }\end{array}$ & $12 / 20,690$ & Tercapai & $15 / 25,862$ & Tercapai \\
\hline 4. & $\begin{array}{l}\text { Mengerjakan } \\
\text { Lembar Kerja }\end{array}$ & $\geq 55$ & $15 / 25,862$ & $\begin{array}{l}\text { Belum } \\
\text { tercapai }\end{array}$ & $56 / 96,552$ & Tercapai & $58 / 100$ & Tercapai \\
\hline 5. & $\begin{array}{l}\text { Aktif } \\
\text { berdiskusi }\end{array}$ & $\geq 30$ & $25 / 43,103$ & Tercapai & $58 / 100$ & Tercapai & $58 / 100$ & Tercapai \\
\hline 6. & $\begin{array}{l}\text { Menjawab } \\
\text { pertanyaan }\end{array}$ & $\geq 80$ & $5 / 8,621$ & $\begin{array}{l}\text { Belum } \\
\text { tercapai }\end{array}$ & $56 / 96,552$ & Tercapai & $58 / 100$ & Tercapai \\
\hline 7. & $\begin{array}{l}\text { Memberi } \\
\text { tanggapan } \\
\text { jawaban }\end{array}$ & $\geq 10$ & $2 / 3,448$ & $\begin{array}{c}\text { Belum } \\
\text { tercapai }\end{array}$ & $5 / 8,621$ & $\begin{array}{c}\text { Belum } \\
\text { tercapai }\end{array}$ & $11 / 18,966$ & Tercapai \\
\hline
\end{tabular}




\begin{tabular}{|l|l|l|l|l|l|l|l|}
\hline \multicolumn{2}{|c|}{ kelompok lain } & & & & & & \\
\hline $\begin{array}{l}\text { Jumlah Rata-rata } \\
\text { Aktivitas Mahasiswa } \\
\text { Keseluruhan }\end{array}$ & 53,571 & 38,916 & $\begin{array}{c}\text { Belum } \\
\text { tercapai }\end{array}$ & 73,930 & Tercapai & 77,833 & Tercapai \\
\hline
\end{tabular}

Berdasarkan data pada Tabel 2, belajar mahasiswa menjadi lebih besar, diperoleh hasil bahwa sebelum diadakan mencermati Lembar Kerja Mahasiswa inovasi metode pembelajaran, aktivitas kuliah dengan disusun lebih operasional, butir-butir mahasiswa secara umum belum memenuhi soal evaluasi disesuaikan tujuan dan indikator target (sebelum LS 38,916 < target 53,571), pembelajaran yang dirumuskan.

kegiatan mencatat dan merangkum saja yang memenuhi target. Setelah dilakukan inovasi metode perkuliahan, yaitu penggunaan metode Examples Non Examples pada Lesson Study 1, terjadi peningkatan aktivitas, yang mulanya hanya 38,916 menjadi 73,930, khususnya pada aktivitas memperhatikan penjelasan dosen dan memberikan tanggapan jawaban masih belum memenuhi target. Catatan lapangan dari observer memberikan masukan yang berharga dalam pelaksanaan refleksi dan perbaikan perencanaan perkuliahan selanjutnya. Hasil catatan lapangan dan rekomendasi dari hasil refleksi dapat dilihat pada Tabel 3.

Berdasarkan hasil observasi dan refleksi Lesson Study 1, maka tim Lesson Study melakukan perbaikan rencana perkuliahan pada Lesson Study 2 dengan menggunakan metode STAD sehingga diharapkan keterlibatan antar anggota kelompok tetap dapat dilakukan, memberi peluang aktivitas

Hasil observasi aktivitas perkuliahan pada Lesson Study 2 menunjukkan semua indikator aktivitas belajar mengalami peningkatan dan memenuhi target belajar yang baik, bahkan aktivitas memperhatikan penjelasan dosen, mencatat dan merangkum, mencatat dan merangkum, mengerjakan Lembar Kerja, aktif berdiskusi, menjawab pertanyaan dilakukan oleh seluruh mahasiswa.

Apabila dihubungkan dengan hasil belajar selama perkuliahannya, menunjukkan adanya peningkatan yang besar, hal ini dapat dilihat pada Tabel 4 dan Tabel 5.

Memperhatikan hasil skor tes baik kelompok maupun individual mengalami peningkatan, baik dari sebelum dilakukan LS maupun antara LS1 dan LS2. Meskipun demikian, ada beberapa catatan dari observer untuk perkuliahan ke depan, yang selengkapnya tertuang pada Tabel 6.

Tabel 3. Hasil Observasi/Catatan Lapangan dan Rekomendasi Refleksi Observer pada LS1

\begin{tabular}{|c|c|}
\hline Catatan Lapangan & Rekomendasi Refleksi Observer \\
\hline $\begin{array}{l}\text {-Perhatian mahasiswa kurang merata, di antara } \\
\text { anggota kelompok masih pasif; } \\
\text { - Mahasiswa kurang siap dalam mengikuti } \\
\text { perkuliahan; } \\
\text {-Keberanian bertanya dan mengemukakan pendapat } \\
\text { masih kurang; }\end{array}$ & $\begin{array}{l}\text {-Perlu pemberian motivasi terus menerus dan } \\
\text { disiapkan metode yang banyak melibatkan aktivitas } \\
\text { mahasiswa; } \\
\text { - Diberikan lembar handout yang bisa dipelajari } \\
\text { sebelum kuliah berlangsung; } \\
\text { - Disiapkan metode yang bisa memotivasi, disediakan } \\
\text { waktu presentasi yang memadai dan setiap individu } \\
\text { dalam kelompok dilibatkan, kerja kelompok } \\
\text { dilombakan, dan pemberian hadiah bagi yang } \\
\text { berprestasi; } \\
\text {-Perlu dirancang Lembar Kerja yang benar-benar } \\
\text { operasional sehingga memudahkan mahasiswa } \\
\text { menyelesaikan kegiatan sesuai Lembar Kerja dan } \\
\text { Evaluasi; }\end{array}$ \\
\hline
\end{tabular}

Tabel 4. Rangkuman Hasil Individual Tes Jaringan Dasar Kelas B Program Studi Pendidikan Biologi

\begin{tabular}{|l|c|c|c|c|c|c|}
\hline \multirow{2}{*}{ No } & Sasaran Pengamatan & \multicolumn{4}{|c|}{ Skor Nilai } \\
\cline { 3 - 7 } & & Sebelum LS & LS1 & $\%$ & LS2 & $\%$ \\
\hline
\end{tabular}




\begin{tabular}{|l|l|l|l|l|l|l|}
\hline & & & & Peningkatan & & Peningkatan \\
\hline 1 & Nilai Tertinggi & 80 & 80 & 0 & 95 & 18,75 \\
\hline 2 & Nilai Terendah & 35 & 40 & 14,286 & 50 & 42,857 \\
\hline 3 & Rata-rata skor nilai & 57,759 & 70,175 & 21,496 & 77,155 & 33,581 \\
\hline
\end{tabular}

Tabel 5. Rangkuman Hasil Kelompok Lembar Kerja Mahasiswa pada Materi Jaringan Dasar Kelas B Program Studi Pendidikan Biologi

\begin{tabular}{|c|c|c|c|c|}
\hline \multirow[t]{2}{*}{ No } & \multirow[t]{2}{*}{ Sasaran Pengamatan } & \multicolumn{3}{|c|}{ Skor Nilai Kegiatan Kelompok } \\
\hline & & LS1 & LS2 & \% Peningkatan \\
\hline 1 & Nilai Tertinggi & 90 & 100 & 11,111 \\
\hline 2 & Nilai Terendah & 75 & 80 & 6,667 \\
\hline 3 & Rata-rata skor nilai & 83,947 & 89,483 & 6,59 \\
\hline
\end{tabular}

Tabel 6. Hasil Observasi/Catatan Lapangan dan Rekomendasi Refleksi Observer pada LS2

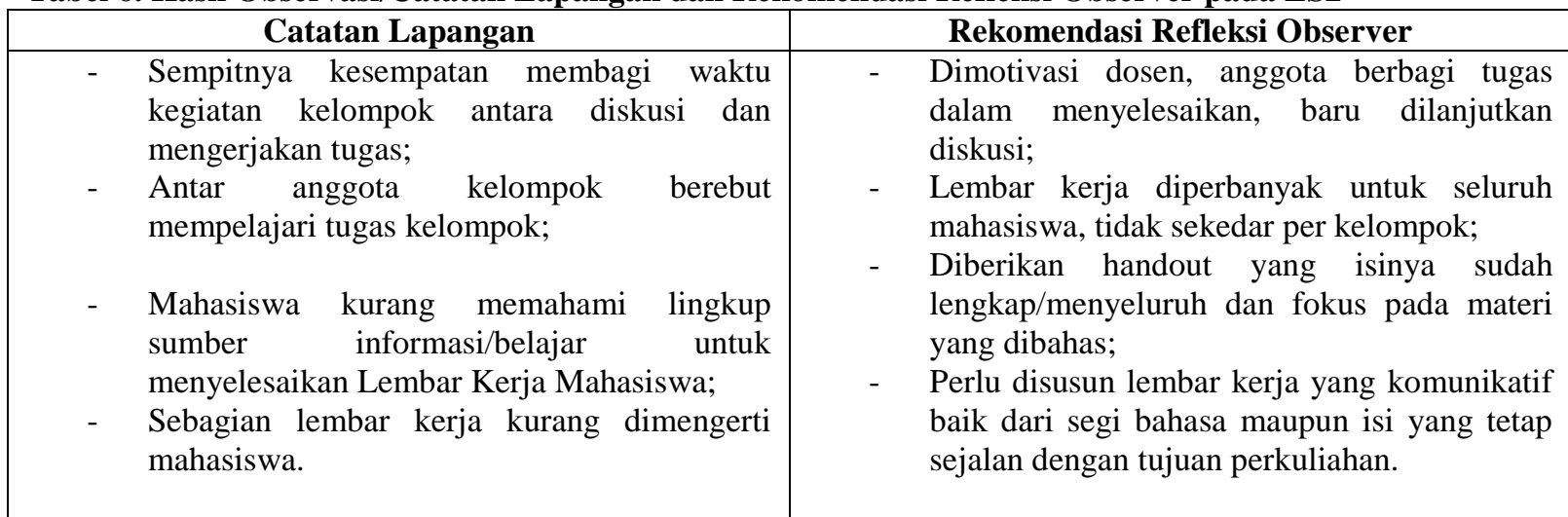

\section{PEMBAHASAN}

Pelaksanaan perkuliahan dengan menerapkan pembelajaran kooperatif model Examples Non Examples dan STAD pada kegiatan Lesson Study Kuliah Struktur Hewan khususnya materi Jaringan Dasar dapat meningkatkan aktivitas dan hasil belajar mahasiswa. Peningkatannya dapat dilihat pada Gambar 2, Gambar 3. a., dan Gambar 3. b.

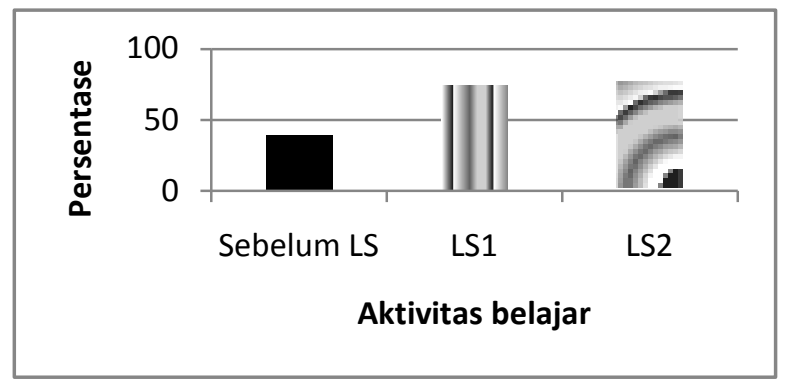

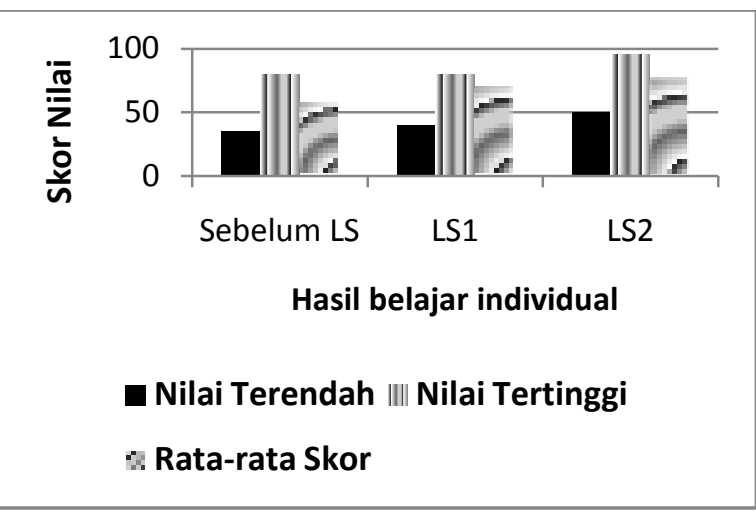

Gambar 3. a. Grafik Peningkatan Hasil Belajar Individual/Mandiri Perkuliahan Struktur Hewan Materi Jaringan Dasar

\section{Gambar 2. Grafik Peningkatan Aktivitas Perkuliahan}




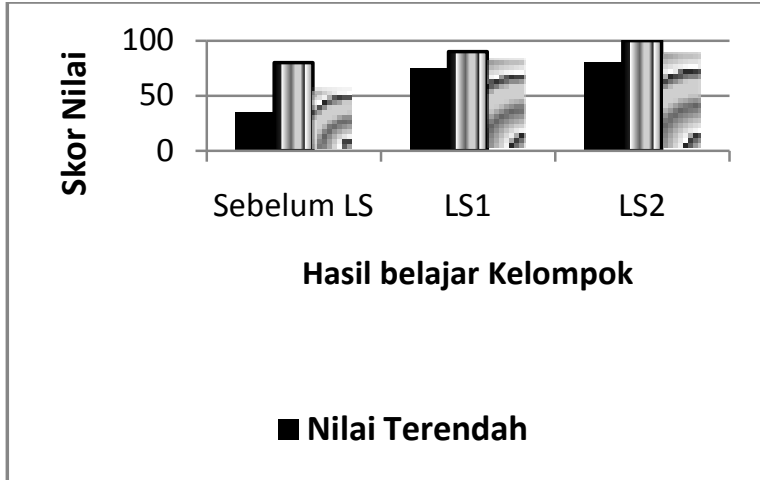

Gambar 3. b. Grafik Peningkatan Hasil Belajar Kelompok Perkuliahan Struktur Hewan Materi Jaringan Dasar

Sebelum dilakukan inovasi metode perkuliahan, aktivitas belajar mahasiswa hanya 38,916\%. Setelah dilakukan Lesson Study 1 meningkat menjadi 73,930\%. Selanjutnya setelah dilakukan refleksi dan diskusi sehubungan temuan dari observer tim Lesson study yang kemudian digunakan sebagai dasar perbaikan dalam perencanaan dan pelaksanaan Lesson study 2, ternyata terjadi peningkatan lagi mencapai 77,833\%, dengan seluruh indikator dapat dicapai. Terhadap hasil tes juga menunjukkan adanya peningkatan. Sebelum dilakukan inovasi metode perkuliahan, hasil belajar mahasiswa rata-rata hanya 57,759. Setelah dilakukan Lesson Study 1 rata-rata skor menjadi 70,175 (meningkat 21,496). Selanjutnya setelah dilakukan refleksi dan diskusi sehubungan temuan dari observer tim Lesson study yang kemudian digunakan sebagai dasar perbaikan dalam perencanaan dan pelaksanaan Lesson study 2, ternyata rata-rata skor menjadi 77,155 (terjadi peningkatan lagi mencapai 33,581\%). Demikian juga terhadap hasil kerja kelompok, yang juga mengalami peningkatan, yaitu pada Lesson Study 1 ratarata skor 83,947. Selanjutnya setelah dilakukan refleksi dan diskusi sehubungan temuan dari observer tim Lesson Study yang kemudian digunakan sebagai dasar perbaikan dalam perencanaan dan pelaksanaan Lesson study 2, ternyata rata-rata skor menjadi 89,483 (terjadi peningkatan lagi mencapai 6,59\%). Hal yang lebih membanggakan adalah bahwa pengubahan metode perkuliahan juga menurunkan skor terendah (sehingga skor terendah menjadi naik skornya) dan meningkatkan skor tertinggi (skor tertinggi juga naik) baik nilai individual maupun kelompok. Pengubahan metode perkuliahan meningkatkan skor tes individual maupun hasil kerja kelompok, menunjukkan kerjasama yang baik dalam kelompok kecil lebih memahamkan pengetahuan pada personalnya/secara individual. Hasil kerja kelompok pada LS1 dan LS2 juga memberi indikasi baik, karena skor terendah, tertinggi, maupun rata-rata tidak jauh berbeda.

Peningkatan pencapaian skor aktivitas dan hasil belajar melalui pembelajaran ini sejalan dengan pemahaman Lundgren (dalam Ibrahim, 2000), bahwa pembelajaran kooperatif di antaranya memberikan manfaat : 1) Meningkatkan pencurahan waktu pada tugas; 2) Rasa harga diri menjadi lebih tinggi; 3) Memperbaiki sikap; 4) Penerimaan terhadap perbedaan individu manjadi lebih besar; 5) Mengurangi sifat apatis; 6) Pemahaman yang lebih mendalam; 7) Meningkatkan motivasi; 8) Memperbesar retensi; 9) Meningkatkan kepekaan, kebaikan, dan toleransi. Sehingga secara umum pembelajaran kooperatif dapat meningkatkan (Ibrahim, 2000): 1) Hasil belajar akademik; 2) Penerimaan terhadap perbedaan individu; 3) serta Meningkatkan pengembangan ketrampilan sosial. Keadaan ini dibuktikan adanya kecenderungan meningkatnya skor nilai individual maupun kelompok, demikian juga meningkatnya skor nilai terendah yang menjadi tinggi maupun skor tertinggi yang menjadi semakin tinggi.

\section{Kesimpulan dan Saran}

Mahasiswa mengalami kesulitan dalam perkuliahan Struktur Hewan, karena materi khususnya tentang Jaringan Dasar terlalu abstrak, tidak berhubungan dengan kehidupan sehari-hari, sehingga sulit dipahami. Oleh karena itu perlu dilakukan visualisasi dan kegiatan kelompok kecil untuk bersama-sama mempelajari materi tersebut dengan serangkaian kegiatan pengamatan terhadap jaringan dasar untuk lebih mengkonkritkan materi yang dibahas.

Penggunaan metode-metode efektif interaktif pembelajaran kooperatif di 
antaranya Example Non Example dan STAD (Student Team Achievement Division)/Tim Pebelajar Kelompok Prestasi yang dilengkapi media LCD untuk menunjukkan gambargambar jaringan dan kedudukannya dalam tubuh hewan serta Lembar Kerja Mahasiswa yang memungkinkan keterlibatan semua anggota dalam kelompok kecil dapat meningkatkan aktivitas dan hasil belajar mahasiswa.

Pelaksanaan Program Lesson Study memberi peluang dosen dalam satu bidang studi bekerjasama menemukan permasalahan perkuliahan dan bersama-sama mencari dan menemukan solusi untuk perbaikan yang lebih tepat dan komprehensif berkaitan permasalahan perkuliahan dalam bidang studinya.

\section{DAFTAR RUJUKAN}

Anonim, 2006. Pembelajaran. Learning with me, (Online), (http://www/IM2. web.id/endyk/activities.htm. ANSTED by learning-with-me, diakses 27 Juni 2007)

Arends, R. 2008. Learning to Teach (Belajar untuk Mengajar). Terjemah oleh Helly Prajitno Soetjipto \& Sri Mulyantini Soetjipto. Yogyakarta: Pustaka Pelajar

Carin, A.A. 1993. Teaching Modern Science. New York: Mcmillan Publishing Company.

Ibrahim, M. 2000. Pembelajaran Kooperatif. Surabaya: Unesa University Press.

Nurkancana, W. 2005. Evaluasi Pendidikan. Jakarta: Usaha Nasional.

Nurmuhammad, 2000. Pengajaran Berpusat Kepada Siswa dan Pendekatan Konstruktivis dalam Pengajaran. Surabaya: Universitas Negeri Surabaya.

Slavin, R. 1994. Educational Psychologi: Teory and Practise. Fourth Edition. Massachusetts. Allyn and Bacon Publishers.

Slavin, R. 1995. Cooperative Learning: Teory and Practise. Fourth Edition.
Massachusetts. Allyn and Bacon Publishers. 